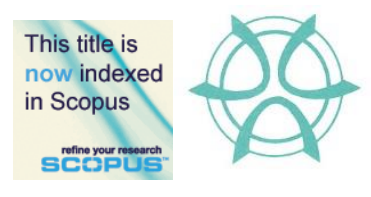

PLANNING MALAYSIA:

Journal of the Malaysian Institute of Planners

VOLUME 15 ISSUE 4 (2017), Page 139 - 150

\title{
REVIEWS ON THE SOCIO-ECONOMIC INDICATORS FOR SPATIAL URBAN SCALE
}

\author{
Illyani Ibrahim¹, Azizan Abu Samah², \& M. Zainora Asmawi ${ }^{3}$ \\ ${ }^{1,3}$ Kulliyyah of Architecture and Environmental Design \\ INTERNATIONAL ISLAMIC UNIVERSITI MALAYSIA \\ ${ }^{2}$ Department of Geography, Faculty of Arts and Social Science, \\ UNIVERSITY OF MALAYA
}

\begin{abstract}
In recent decades, socio-economic variables have been widely used to investigate regional scale particularly in climate change studies. This paper aims to review appropriate socio-economic indicators for studies related to environment and climate at the level of spatial urban scale. It has been a challenge to select appropriate indicators because the interrelationship between human interference and the environment has proved difficult to be understood. The method used for the review is content analysis. The finding proposes the future research to choose suitable socio-economic indicators by referring to the scale of study and the spatial coverage of the topic. This article also provides a socio-economic framework to ensure that the appropriate of urban scale is the key aspect for selection of indicators in environmental and climate related studies.
\end{abstract}

Keyword: Environment, socio-economic indicators, urban scale

Date Received: $11^{\text {th }}$ May 2017

Date of Acceptance: $27^{\text {th }}$ November 2017 
Illyani Ibrahim, Azizan Abu Samah, \& M. Zainora Asmawi

Reviews On the Socio-Economic Indicators for Spatial Urban Scale

\section{INTRODUCTION}

An assessment of indicators' relevance is required to ensure accurate information on the effect of climate on processes specifically the relationship between the local environment and human activities. Selecting the right indicators is important in order to refine the understanding of the linkages between the dynamic of climate and the socio-economic indicators. Although humans and the environment are interrelated, a very limited effort has been appropriately done to an assessment of socio-economic indicators in relation to environment (Bowen \& Riley, 2003; Marin \& Modica, 2017).

An indicator is a direct measure, proxy, or index used to understand, evaluate, and communicate the impacts and vulnerabilities that result from climate change and variability (Kenney et al., 2012). It is also a constructed measure of several variables that are combined to assess a particular problem that could not be captured using a single measure or proxy (Keeney \& Gregory, 2005). In other words, an indicator used for urban scale analysis should be spatially measureable because climate is closely related to space. The identification of indicators should also be relevant with environment policy, thus there is a need to assess the policies using indicators that may impact the environment.

Indicators should be described by dynamic measures in order to understand and minimise the number of variables (Bowen \& Riley, 2003). The characteristics of a good indicator should be measureable, precise, and reliable. The indicator is measureable in the sense that it can be quantified by using tools or methods. An indicator is considered precise in the sense that it is a defined tool and is direct toward the objective, which can avoid confusion. The indicator is also reliable by time intervals and by different observers.

Many studies have discussed the impact of socio-economic indicators to health (Galobardes et al., 2006; Turrell et al., 2002), and climate change (Hoornweg et al.,, 2011; Masson et al., 2014; Schlünzen \& Bohnenstengel, 2016), but very few were conducted in an urban setting. Planners used to plan the future of an area mostly by looking at the socio-economic needs (Ng \& Ren, 2015) without providing information on the climate. "Climate information" was rarely included at the strategic level, despite the planners having learned the importance of climate at university level. Yet, earlier study have attested the necessity of socio-economic factors to be implemented at the urban scale (Goodchild, Anselin, \& Deichmann, 1993). Ng \& Ren (2015) particularly noted that besides preparing a master plan, the economic and socio-economic benefits need to be stated as well. This gap points to the need to understand the link among socioeconomic factors at urban scale.

Thus, the objective of this review is to analyse the selected socio-economic indicators specifically at urban scale. Socio-economic indicators for spatial analysis used in previous studies are reviewed in order to understand the methods 
of the indicators' selection from a climatic perspective. Content analysis is used to achieve the study objective, covering range of related studies in climatic, socioeconomic, environmental and urban planning.

\section{ENVIRONMENT AND SOCIO-ECONOMIC INDICATORS}

There are many studies conducted in several particular themes in relation to environmental and socio-economic indicator, ranging from the urban form, urban climate, air pollution, environmental study, urban growth, urban forest and urban infrastructure. It is a challenge to capture the alternate approach to understand the relationship between the environment and socio-economic indicators (Chrysoulakis et al., 2014). Each city has its own socio-economic and physical attributes and conditions that should be reflected in a scientific analysis and climate policy formation (Lee \& Painter, 2015). Hence, the governing parties, such as local experts, local governments, and policymakers should cooperate with the local communities to understand the challenges and solutions for particular climatic problems.

All themes of development have different scale of spatial climate studies; either such study is a regional, global, meso or micro scale. Thus, scale analysis should be appropriately done before any measure of indicators is conducted. This is to ensure that the identified result explained what is the real scenario is about. By understanding the scale of spatial climate studies (such as regional, local, and micro scales), socio-economic indicators can be determined appropriately. Each indicator measures can give a different interpretation. The dimensions also vary; the spatial dimensions are measured in continuous scale, whereas the socioeconomic dimension is observed based on average on over finite areas.

Spatial studies such as the urban form, urban growth, urban forest and urban infrastructure usually up to the urban level only; which can be identified as a local scale. A micro study; such as township level should use a micro indicator only. An urban climate, air pollution and environmental study, however, depends on the type of the scale; thus it is important to know the objectives of the research to be conducted.

Literatures in related studies indicate that authors tried to establish a relationship between different climate/spatial data and socio-economic data. An earlier study by Goodchild et al., (1993) proposed a general framework to integrate spatially referenced socio-economic data from heterogeneous sources, which can be digitised using geographical information system (GIS), but no further related research had been conducted until the recent research (PlumejeaudPerreau et al., 2015). Prior studies have also shown that analysing socio-economic indicators can be linked with urban scale. One local-scale study by Khalyani et al. (2013) aimed to understand the relationship between socio-economic data (income data for population in urban and rural) and climatic variables (such as 
Illyani Ibrahim, Azizan Abu Samah, \& M. Zainora Asmawi

Reviews On the Socio-Economic Indicators for Spatial Urban Scale

mean annual rainfall and mean annual temperature). The study found that forest loss was due to the increase in urban population and the forest drying induced by climate change, but this trend has not occurred in the rural setting. Nesbitt and Meitner (2016) found a high correlation between vegetation cover and population density, house age, income, and race respectively and the importance of different measures of access to urban forest.

The availability of temporal remote sensing datasets supports the potential for an assessments of urban environmental quality and the quality of life. The selection of algorithm for remote sensing should rely on the purpose of each indicator and its impact on urban sustainability. The development of remote sensing is crucial because the information behind it should not be denied. The improved processing and development of algorithm has given a paradigm shift to the understanding of the real problem on the earth surface. Moderate resolution imaging spectoradiometer (MODIS) was used to link socio-economic indicators with environment (Grekousis, Mountrakis, \& Kavouras, 2016). The information derived from remote sensing can be directly related to measuring important socioeconomic impacts. Another research by Jing et al., (2016) found that indicators of human-related activity have a good correlation with the day-night band of the Visible Infrared Imaging Radiometer Suite (VIIRS) composite.

The selection of appropriate indicators is important for policy making in order to measure the condition and trends and to re-examine an ineffective policy. Several problems have been discovered including the availability of data and all social, economic, and environmental datasets are available on an annual basis. Another problem encountered was that many data were generated at a very high cost. Koomen (2003) interpreted several indicators that can be used to measure spatial analysis, which are population/demography, economic activity, and available facilities. These indicators are measured in terms of structure (actual state) and performance (development over time), and they are able to measure quantitatively and be analysed over time.

\section{REVIEW ANALYSIS AND DISCUSSION}

\section{Indicators for Urban Scale}

To evaluate the current knowledge on the interaction between socio-economic indicators and urban scale, a total of 48 studies on socio-economic indicators in urban scale were reviewed (Table 1). 
PLANNING MALAYSIA:

Journal of the Malaysia Institute of Planners (2017)

Table 1 Summary of Socio-economic Indicators in Urban Scale Analysis

\begin{tabular}{|c|c|c|c|c|c|}
\hline & $\begin{array}{l}\text { Economic } \\
\text { Indicators }\end{array}$ & $\begin{array}{l}\text { Social } \\
\text { Indicators }\end{array}$ & Author & Main variable & Scale \\
\hline 1 & GDP per capita & & $\begin{array}{l}\text { (Huang, Lu, \& Sellers, } \\
\text { 2007; Schwarz, 2010; } \\
\text { United Nation Statistics } \\
\text { Division, n.d.) }\end{array}$ & Income & Local \\
\hline 2 & & $\begin{array}{l}\text { Population } \\
\text { number }\end{array}$ & (Schwarz, 2010) & Population & Local \\
\hline 3 & & $\begin{array}{l}\text { Population } \\
\text { distribution }\end{array}$ & (Schwarz, 2010) & Population & Local \\
\hline 4 & & $\begin{array}{l}\text { Density of } \\
\text { housing }\end{array}$ & (Schwarz, 2010) & Housing & Local \\
\hline 5 & & $\begin{array}{l}\text { Number of } \\
\text { vehicles }\end{array}$ & (Schwarz, 2010) & Transportation & Local \\
\hline 6 & & $\begin{array}{l}\text { Local population } \\
\text { estimation }\end{array}$ & (Jensen \& Cowen, 1999) & Population & Local \\
\hline 7 & Quality of life & & (Jensen \& Cowen, 1999) & Housing & Local \\
\hline 8 & Total GDP & & $\begin{array}{l}\text { (Gong, Yu, Joesting, \& } \\
\text { Chen, 2013) }\end{array}$ & Income & Local \\
\hline 9 & $\begin{array}{l}\text { GDP of } \\
\text { agriculture, } \\
\text { industries and } \\
\text { professions }\end{array}$ & & (Gong et al., 2013) & Income & Local \\
\hline 12 & $\begin{array}{l}\text { Local } \\
\text { government } \\
\text { revenue }\end{array}$ & & (Gong et al., 2013) & Income & Local \\
\hline 13 & $\begin{array}{l}\text { Resident income } \\
\text { per capita }\end{array}$ & & (Gong et al., 2013) & Income & Local \\
\hline 14 & & $\begin{array}{l}\text { Total resident } \\
\text { population }\end{array}$ & (Gong et al., 2013) & Population & Local \\
\hline 15 & & $\begin{array}{l}\text { Total resident } \\
\text { household }\end{array}$ & (Gong et al., 2013) & Population & Local \\
\hline 16 & & $\begin{array}{l}\text { Natural increase } \\
\text { of resident } \\
\text { population }\end{array}$ & (Gong et al., 2013) & Population & Local \\
\hline 17 & & Migrant increase & (Gong et al., 2013) & Population & Local \\
\hline 18 & $\begin{array}{l}\text { Total } \\
\text { construction area } \\
\text { of urban green } \\
\text { land (ha) }\end{array}$ & & (Gong et al., 2013) & Population & Local \\
\hline 19 & & $\begin{array}{l}\text { Population } \\
\text { density }\end{array}$ & $\begin{array}{l}\text { (Frenkel \& Orenstein, } \\
\text { 2012; United Nation } \\
\text { Statistics Division, n.d.; } \\
\text { Viguié, Hallegatte, \& } \\
\text { Rozenberg, 2014) }\end{array}$ & Population & Local \\
\hline 20 & & $\begin{array}{l}\text { Population } \\
\text { density }\end{array}$ & $\begin{array}{l}\text { (Plumejeaud-Perreau et al., } \\
\text { 2015) }\end{array}$ & Population & Micro \\
\hline 20 & & $\begin{array}{l}\text { The number of } \\
\text { households living } \\
\text { in collective } \\
\text { housings }\end{array}$ & $\begin{array}{l}\text { (Plumejeaud-Perreau et al., } \\
\text { 2015) }\end{array}$ & Housing & Micro \\
\hline 21 & & $\begin{array}{l}\text { the number of } \\
\text { proprietary } \\
\text { households, }\end{array}$ & $\begin{array}{l}\text { (Plumejeaud-Perreau et al., } \\
\text { 2015) }\end{array}$ & Housing & Micro \\
\hline
\end{tabular}


Illyani Ibrahim, Azizan Abu Samah, \& M. Zainora Asmawi

Reviews On the Socio-Economic Indicators for Spatial Urban Scale

\begin{tabular}{|c|c|c|c|c|c|}
\hline 22 & & $\begin{array}{l}\text { the surface of } \\
\text { their housings }\end{array}$ & $\begin{array}{l}\text { (Plumejeaud-Perreau et al., } \\
\text { 2015; Viguié et al., 2014) }\end{array}$ & Housing & Micro \\
\hline 23 & $\begin{array}{l}\text { Income ranges of } \\
\text { household }\end{array}$ & & $\begin{array}{l}\text { (Chakraborty, 2009; } \\
\text { Plumejeaud-Perreau et al., } \\
\text { 2015) }\end{array}$ & Income & Micro \\
\hline 24 & $\begin{array}{l}\text { Real GDP per } \\
\text { capita growth } \\
\text { rate }\end{array}$ & & $\begin{array}{l}\text { (United Nation Statistics } \\
\text { Division, n.d.) }\end{array}$ & Income & Meso \\
\hline 25 & $\begin{array}{l}\text { Production and } \\
\text { consumption } \\
\text { patterns }\end{array}$ & & $\begin{array}{l}\text { (United Nation Statistics } \\
\text { Division, n.d.) }\end{array}$ & Income & Meso \\
\hline 26 & $\begin{array}{l}\text { Investment share } \\
\text { in GDP }\end{array}$ & & $\begin{array}{l}\text { (United Nation Statistics } \\
\text { Division, n.d.) }\end{array}$ & Income & Meso \\
\hline 27 & & $\begin{array}{l}\text { Population } \\
\text { growth rate }\end{array}$ & $\begin{array}{l}\text { (United Nation Statistics } \\
\text { Division, n.d.) }\end{array}$ & Population & Meso \\
\hline 28 & & $\begin{array}{l}\text { Urban/rural } \\
\text { migration rate }\end{array}$ & $\begin{array}{l}\text { (United Nation Statistics } \\
\text { Division, n.d.) }\end{array}$ & Population & Meso \\
\hline 29 & & $\begin{array}{l}\text { Calorie supply } \\
\text { per capita }\end{array}$ & $\begin{array}{l}\text { (United Nation Statistics } \\
\text { Division, n.d.) }\end{array}$ & Health & Meso \\
\hline 30 & $\begin{array}{l}\text { Population size } \\
\text { (region and } \\
\text { locality) }\end{array}$ & & $\begin{array}{l}\text { (Frenkel \& Orenstein, } \\
\text { 2012) }\end{array}$ & Population & Local \\
\hline 31 & $\begin{array}{l}\text { Population } \\
\text { growth (region } \\
\text { and locality) }\end{array}$ & & $\begin{array}{l}\text { (Frenkel \& Orenstein, } \\
\text { 2012) }\end{array}$ & Population & Local \\
\hline 32 & $\begin{array}{l}\text { Proportional of } \\
\text { population size } \\
\text { and growth }\end{array}$ & & $\begin{array}{l}\text { (Frenkel \& Orenstein, } \\
\text { 2012) }\end{array}$ & Population & Local \\
\hline 33 & & $\begin{array}{l}\text { Built space } \\
\text { divided } \\
\text { population size } \\
(\%)\end{array}$ & $\begin{array}{l}\text { (Frenkel \& Orenstein, } \\
\text { 2012) }\end{array}$ & Population & Local \\
\hline 34 & & $\begin{array}{l}\text { Single-family } \\
\text { and duplex } \\
\text { versus high-rise } \\
\text { building }\end{array}$ & $\begin{array}{l}\text { (Frenkel \& Orenstein, } \\
\text { 2012) }\end{array}$ & Population & Local \\
\hline 35 & $\begin{array}{l}\text { Vehicles per } \\
\text { household }\end{array}$ & & $\begin{array}{l}\text { (Chakraborty, 2009; } \\
\text { Frenkel \& Orenstein, 2012) }\end{array}$ & Transportation & Local \\
\hline 36 & $\begin{array}{l}\text { Percentage labor } \\
\text { force working } \\
\text { outside of home } \\
\text { community }\end{array}$ & & $\begin{array}{l}\text { (Frenkel \& Orenstein, } \\
\text { 2012) }\end{array}$ & Population & Local \\
\hline 37 & $\begin{array}{l}\text { National main } \\
\text { telephone } \\
\text { lines } / 1000 \text { people }\end{array}$ & & (Huang et al., 2007) & Facilities & Local \\
\hline 38 & $\begin{array}{l}\text { Vehicle/1000 } \\
\text { population }\end{array}$ & & (Huang et al., 2007) & Transportation & Local \\
\hline 39 & Employment & & (Chakraborty, 2009) & Quality of life & Local \\
\hline 40 & $\begin{array}{l}\text { Land and real } \\
\text { estate values }\end{array}$ & & (Viguié et al., 2014) & Income & Local \\
\hline 41 & Unemployment & & & Crime & \\
\hline 42 & & Poverty & (Brochu et al., 2011) & Air pollution & Local \\
\hline 43 & & Education & (Brochu et al., 2011) & Air pollution & Local \\
\hline 44 & Income & & (Brochu et al., 2011) & Air pollution & Local \\
\hline 45 & Mean income & & $\begin{array}{l}\text { (Habermann, Souza, Prado, } \\
\text { \& Gouveia, 2014) }\end{array}$ & Air pollution & Local \\
\hline
\end{tabular}


PLANNING MALAYSIA:

Journal of the Malaysia Institute of Planners (2017)

\begin{tabular}{|c|c|c|c|c|}
\hline 46 & $\begin{array}{l}\text { The \% of } \\
\text { households } \\
\text { connected to the } \\
\text { sewage system }\end{array}$ & (Habermann et al., 2014) & Air pollution & Local \\
\hline 47 & Occupation & $\begin{array}{l}\text { (Fernández-Somoano, } \\
\text { Hoek, \& Tardon, 2013) }\end{array}$ & Air pollution & Local \\
\hline 48 & Educational level & $\begin{array}{l}\text { (Fernández-Somoano et al., } \\
\text { 2013) }\end{array}$ & Air pollution & Local \\
\hline
\end{tabular}

The scale of area demonstrates that local is the main scale used to analyses the indicators. As such, the content analysis confirms that little attention has been given on the use of socio-economic indicators towards urban scale. It is unclear as to how socio-economic indicators in local climate are selected because they are newly addressed (Lee \& Painter, 2015; Sethi \& de Oliveira, 2015), although they were already proposed in earlier studies (Goodchild et al., 1993). Yet, many researchers who have adopted the socio-economic indicators towards climate change have debated the subject in this century (Greer, $\mathrm{Ng}$, \& Fisman, 2008; Schlünzen \& Bohnenstengel, 2016; Sethi \& de Oliveira, 2015; Singh, 2010). However, it was found that some of the researches give focus to the urban form and urban growth analysis, i.e. nine and seven studies respectively. This review discovers that very lacking studies was found in the urban climate analysis as only recently this topic has emerged by researchers ( $\mathrm{Ng} \&$ Ren, 2015) as it is crucial to understand the behaviour of socio-economic analysis in the urban area, although it has widely used in the climate change study.

\section{Socio-Economic Indicators}

The finding also shows that GDP is the method adopted by most researchers (Gong et al., 2013; Plumejeaud-Perreau et al., 2015) as the economic indicator. However, it must be understood that adopting the method would not yield a scenario that is better or worse. For example, if one needs to measure the quality of life, using GDP would not be a good indicator. The increase of goods production will give a higher GDP, but environmental damage and health (noise or pollution) will not be considered, which indirectly gives a lower quality of life. Therefore, each of the elements should be seen from the objective of the study in order to scrutinize appropriate indicators.

Population density is also another indicator used to measure social indicators (Plumejeaud-Perreau et al., 2015; Schwarz, 2010; United Nation Statistics Division, n.d.). It should be concerned that if population density in an area is higher, the urban scale can be deteriorated. For example, Elsayed (2012) reported that higher population density may increase temperature value, and higher population density may increase pollution risk because the increased use of vehicles can increase the amount of carbon monoxide to the earth surface. Types of houses and household amounts (Frenkel \& Orenstein, 2012; Gong et al., 2013; 
Illyani Ibrahim, Azizan Abu Samah, \& M. Zainora Asmawi

Reviews On the Socio-Economic Indicators for Spatial Urban Scale

Plumejeaud-Perreau et al., 2015) are also among the socio-economic indicators used to measure the individual trend of residents for particular years.

Further analysis has attested the lack of consistency between the scale of study and the indicators used. For example, studies in the urban scale (local scale) should have adopted GDP per capita and not the total GDP because the coverage of local area is not as wide as that of regional studies, which can cover a whole country. The latter case, if concern regional scale, justifies the use of total GDP. For urban studies, local scale can be used because it covers between $100 \mathrm{~m}$ to 1 $\mathrm{km}$. Thus, it is important to understand that remote sensing data is different in terms of pixel size. For a broader image such as MODIS data, the pixel size is $1 \mathrm{~km} \times 1 \mathrm{~km}$. This type of image can adopt total GDP because it covers regional areas. In this regards, Table 2 demonstrates the relevant suitable indicators to be used depending on the field and topic of studies.

Table 2 Summary of Relevant Indicators According to Field and Topic

\begin{tabular}{|c|c|c|}
\hline Field & Topic & $\begin{array}{l}\text { The relevance of indicators in the urban } \\
\text { scale }\end{array}$ \\
\hline Urban form & $\begin{array}{l}\text { Analysis of the urban form, } \\
\text { morphology of the city and } \\
\text { urban growth study }\end{array}$ & $\begin{array}{l}\text { GDP per capita, population number, } \\
\text { population distribution, density of housing, } \\
\text { number of vehicle, household income, } \\
\text { telephone lines }\end{array}$ \\
\hline Urban climate & $\begin{array}{l}\text { Climate analysis including } \\
\text { meteorology and climatology } \\
\text { analysis }\end{array}$ & $\begin{array}{l}\text { Number of households, population density, } \\
\text { the housing surface }\end{array}$ \\
\hline Air pollution & $\begin{array}{l}\text { Environmental problems; } \mathrm{CO} 2 \\
\text { and other polluted gases, related } \\
\text { to other variables }\end{array}$ & $\begin{array}{l}\text { Unemployment, education, income, mean } \\
\text { income, household connected to sewage } \\
\text { system, occupation, education level }\end{array}$ \\
\hline Environmental study & $\begin{array}{l}\text { Open topic, particularly on air, } \\
\text { soil and water issues }\end{array}$ & $\begin{array}{l}\text { GDP per capita, production and } \\
\text { consumption, investment share, population } \\
\text { growth, Urban rural migration rate, calorie } \\
\text { supply per capita, vehicle }\end{array}$ \\
\hline Urban growth & $\begin{array}{l}\text { Analysis on the increment of } \\
\text { urban changes due to the intense } \\
\text { of urbanization }\end{array}$ & $\begin{array}{l}\text { Population size, population growth, } \\
\text { density, family in terrace vs high rise } \\
\text { building, vehicle per household, labour } \\
\text { force percentage }\end{array}$ \\
\hline Urban forest & $\begin{array}{l}\text { Analysis focuses on the temporal } \\
\text { study in urban forest } \\
\text { fragmentation, carbon analysis } \\
\text { and land cover analysis }\end{array}$ & $\begin{array}{l}\text { Total GDP, GDP industries, GDP } \\
\text { agriculture, GDP other professions, local } \\
\text { government revenue, resident income per } \\
\text { capita, total population, total household, } \\
\text { increase of population }(\%) \text {, migrant } \\
\text { increase of population }\end{array}$ \\
\hline Urban infrastructure & $\begin{array}{l}\text { Understanding on the population } \\
\text { and infrastructure in urban or } \\
\text { rural area }\end{array}$ & Population, quality of life \\
\hline
\end{tabular}

Whilst, the proposed model shown in Figure 1 is intended to serve as a framework to facilitate the process of collecting information on the socioeconomic indicators at the level of urban scale. 


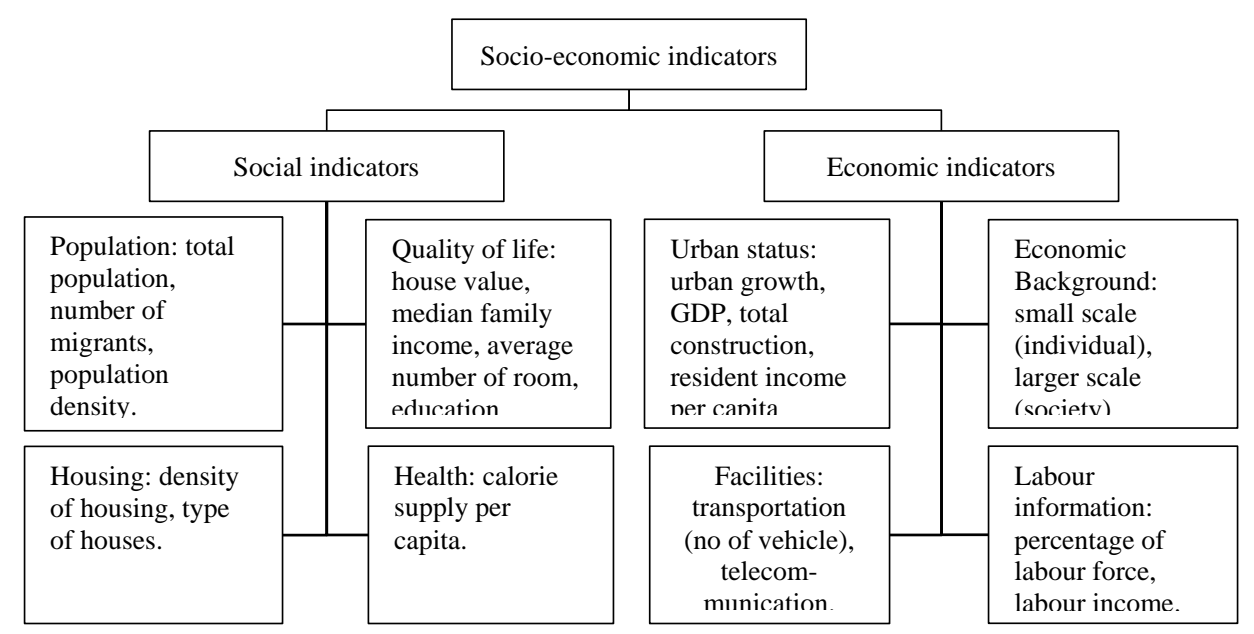

Figure 1 A conceptual model for socio-economic data collection associated with urban scale study

Each factor is categorised into each particular indicator that is related from the analysis in Table 1. The framework can facilitate planners to prioritise the important elements of socio-economic indicators that need to be used in the particular studies.

\section{CONCLUSION}

This paper reviews the current state of knowledge on socio-economic indicators in the urban scale setting. Understanding human-induced activities such as deforestation and air pollution can facilitate the understanding of individual or society role towards the environment. This paper suggests appropriate socioeconomic indicators to be used in any urban scale and provides the conceptual framework. In fact, understanding the relationship between the socio-economic indicators towards environment is very crucial because it deals with different dimensions such as, regional, meso, local and micro.

\section{ACKNOWLEDGEMENT}

This study is funded by the Research Initiative Grant Scheme (RIGS) RIGS15025-0025 from International Islamic University Malaysia (IIUM).

\section{REFERENCES}

Bowen, R. E., \& Riley, C. (2003). Socio-economic indicators and integrated coastal management. Ocean and Coastal Management, 46(3-4), 299-312. 
Illyani Ibrahim, Azizan Abu Samah, \& M. Zainora Asmawi

Reviews On the Socio-Economic Indicators for Spatial Urban Scale

Brochu, P. J., Yanosky, J. D., Paciorek, C. J., Schwartz, J., Chen, J. T., Herrick, R. F., \& Suh, H. H. (2011). Particulate air pollution and socioeconomic position in rural and urban areas of the northeastern United States. American Journal of Public Health, 101(Suppl 1), S224-S230.

Chakraborty, M. (2009). An approach towards urban form analysis and landuse classification: A case of Ahmedabad, India. International Institute for Geoinformation Science and Earth Observation Enschede, The Netherlands.

Chrysoulakis, N., Feigenwinter, C., Triantakonstantis, D., Penyevskiy, I., Tal, A., Parlow, E., Marconcini, M. (2014). A conceptual list of indicators for urban planning and management based on earth observation. ISPRS Int. J. GeoInf, 3, 980-1002.

Elsayed, I. S. M. (2012). Effects of population density and land management on the intensity of urban heat islands: a case study on the city of Kuala Lumpur, Malaysia. In B. Monwar (Ed.), Application of geographic information systems (pp. 267-283). Rijeka: InTech.

Fernández-Somoano, A., Hoek, G., \& Tardon, A. (2013). Relationship between area-level socioeconomic characteristics and outdoor $\mathrm{NO}^{2}$ concentrations in rural and urban areas of northern Spain. BMC Public Health, 13, 1. http://doi.org/10.1186/1471-2458-13-71

Frenkel, A., \& Orenstein, D. E. (2012). Can Urban growth management work in an era of political and economic change? Journal of the American Planning Association, 78(1), 16-33.

Galobardes, B., Shaw, M., Lawlor, D. A., \& Lynch, J. W. (2006). Indicators of socioeconomic position (Part 1). Journal of Epidemiology and Community Health, 60(1), 7-12.

Gong, C., Yu, S., Joesting, H., \& Chen, J. (2013). Determining socioeconomic drivers of urban forest fragmentation with historical remote sensing images. Landscape and Urban Planning, 117, 57-65.

Goodchild, M. F., Anselin, L., \& Deichmann, U. (1993). A framework for the areal interpolation of socioeconomic data. Environment and Planning $A$, 25(3), 383-397.

Greer, A., Ng, V., \& Fisman, D. (2008). Climate change and infectious diseases in North America: The road ahead. Canadian Medical Association Journal, 178(6), 715-722.

Grekousis, G., Mountrakis, G., \& Kavouras, M. (2016). Linking MODIS-derived forest and cropland land cover 2011 estimations to socioeconomic and environmental indicators for the European Union's 28 countries. GIScience \& Remote Sensing, 53(1), 122-146.

Habermann, M., Souza, M., Prado, R., \& Gouveia, N. (2014). Socioeconomic inequalities and exposure to traffic-related air pollution in the city of Sao Paulo, Brazil. Cad Saude Publica, 30(1), 119-125.

Hoornweg, D., Freira, M., Lee, M. J., Bhada-Tata, P., \& Yuen, B. (Eds.) (2011). 
Cities and climate change: Responding to an urgent Agenda. Washington D.C.: The World Bank.

Huang, J., Lu, X. X., \& Sellers, J. M. (2007). A global comparative analysis of urban form: Applying spatial metrics and remote sensing. Landscape and Urban Planning, 82(4), 184-197.

Jensen, J., \& Cowen, D. (1999). Remote sensing of urban suburban infrastructure and socio-economic attributes. Photogrammetric Engineering and Remote Sensing, 65(5), 611-622.

Jing, X., Shao, X., Cao, C., Fu, X., \& Yan, L. (2016). Comparison between the Suomi-NPP day-night band and DMSP-OLS for correlating socioeconomic variables at the provincial level in China. Remote Sensing, 8(1), $1-24$.

Keeney, R. L., \& Gregory, R. S. (2005). Selecting attributes to measure the achievement of objectives. Operations Research, 53, 1-11.

Kenney, M. A., Chen, R. S., Maldonado, J., \& Quattrochi, D. (2012). Climate change impacts and responses: Societal indicators for the national climate assessment. National Climate Assessment (NCA), 5c, 1-111.

Khalyani, A. H., Mayer, A. L., Falkowski, M. J., \& Muralidharan, D. (2013). Deforestation and landscape structure changes related to socioeconomic dynamics and climate change in Zagros forests. Journal of Land Use Science, 8(3), 321-340.

Koomen, E. (2003). Spatial analysis in support of physical planning (Dissertation). Vrije Universiteit, Amsterdam.

Lee, T., \& Painter, M. (2015). Urban climate comprehensive local climate policy : The role of urban governance. Urban Climate, 14, 566-577.

Marin, G., \& Modica, M. (2017). Socio-economic exposure to natural disasters. Environmental Impact Assessment Review, 64, 57-66.

Masson, V., Marchadier, C., Adolphe, L., Aguejdad, R., Avner, P., Bonhomme, M., ... Zibouche, K. (2014). Adapting cities to climate change: A systemic modelling approach. Urban Climate, 10(P2), 407-429.

Nesbitt, L., \& Meitner, M. J. (2016). Exploring relationships between socioeconomic background and urban greenery in Portland, OR. Forests, 7(8), 1-14.

$\mathrm{Ng}$, E., \& Ren, C. (Eds.) (2015). The urban climatic map for sustainable urban planning. New York: Routledge.

Plumejeaud-Perreau, C., Poitevin, C., Plumejeaud-perreau, C., Poitevin, C., \& Build, N. L. (2015, July). Building local climate zones by using socioeconomic and topographic vectorial databases. ICUC9, July 20-24 July, Toulouse, France.

Schlünzen, K. H., \& Bohnenstengel, S. I. (2016). Socio-economic impacts: Urban climate. In M. Quante and F. Colijn (Eds.), North Sea region climate change assessment (pp. 417-429). Springer International Publishing. 
Illyani Ibrahim, Azizan Abu Samah, \& M. Zainora Asmawi

Reviews On the Socio-Economic Indicators for Spatial Urban Scale

Schwarz, N. (2010). Urban form revisited-Selecting indicators for characterising European cities. Landscape and Urban Planning, 96(1), 29-47.

Sethi, M., \& de Oliveira, J. P. (2015). From global "North-South" to local "Urban-Rural": A shifting paradigm in climate governance? Urban Climate, 14, 529-543.

Singh, M. K. (2010). Socio-economics of climate change (impact on agriculture land use changes in India) (Doctoral dissertation). Szent István University, Gödöllö.

Turrell, G., Hewitt, B., Patterson, B., \& Oldenburg, B. (2002). Socioeconomic differences in food purchasing behaviour and suggested implications for diet-related health promotion. J Hum Nutr Diet., 15(5), 355-364.

United Nation Statistics Division. (n.d.). Environmental indicators. Retrieved October

12 , 2016 ,

from http://unstats.un.org/unsd/environment/indicators.htm

Viguié, V., Hallegatte, S., \& Rozenberg, J. (2014). Downscaling long term socioeconomic scenarios at city scale: A case study on Paris. Technological Forecasting and Social Change, 87, 305-324. 